Original Paper

\title{
Pengelolaan Sampah Rumah Tangga Menjadi Pupuk Organik Menggunakan Komposter di Lingkungan Desa Montong Baan Selatan, Kecamatan Sikur, Kabupaten Lombok Timur
}

\author{
Susilawati $^{*}$, Daniel Rinengkuh Tinarja², Fedik Novibriawan ${ }^{3}$, Dewi Komala \\ Adilatussiam ${ }^{3}$, Nia Audina Zein ${ }^{4}$, Meta Yunia Prastika ${ }^{5}$, Nina Parwati ${ }^{5}$, Ratnah$^{6}$, \\ Widia Nila Risnadewi ${ }^{7}$
}

\author{
${ }^{1}$ Pendidikan Fisika, Fakultas Keguruan Dan Ilmu Pendidikan, Universitas Mataram. \\ ${ }^{2}$ Ilmu Hukum, Fakultas Hukum, Universitas Mataram. \\ ${ }^{3}$ Pendidikan Guru Sekolah Dasar, Fakultas Keguruan Dan Ilmu Pendidikan, Universitas Mataram. \\ ${ }^{4}$ Pendidikan Bahasa Inggris, Fakultas Keguruan Dan Ilmu Pendidikan, Universitas Mataram. \\ ${ }^{5}$ Ilmu Sosiologi, Fakultas Ilmu Sosial Dan Politik, Universitas Mataram. \\ ${ }^{6}$ Pertanian, Fakultas Pertanian Dan Peternakan, Universitas Mataram. \\ ${ }^{7}$ Farmasi, Fakultas Kedokteran, Universitas Mataram.
}

*Corresponding Author:
Susilawati, Pendidikan Fisika,
Fakultas Keguruan Dan Ilmu
Pendidikan, Universitas
Mataram, Indonesia;
Email:
susilawatihambali@unram.co.id

\section{Pendahuluan}

Sampah merupakan masalah masyarakat yang sampai sekarang penanganannya belum menyuluruh bahkan di beberapa tempat belum ada sistem penanggulangan yang jelas dimana mengakibatkan sampah menumpuk dimana mana, serta kebiasaan masyarakat yang buruk seperti membuang sampah di sungai atau aliran air yang ada dapat menyebabkan polusi air dan kerusakan ekosistem air. Banyaknya masalah yang dapat ditimbulkan oleh penanggulangan sampah yang tidak efektif ini harusnya menjadi perhatian kita semua sebagai

\begin{abstract}
South Montong Baan Village is one of the villages in East Lombok Regency which the majority of the people there rely heavily on the agricultural sector. The problem still faced by the locals is that the lack of awareness in managing the waste. An alternative way offered to overcome the situations by educating the locals on how to make use of domestic waste and training, producing, making use, monitoring, and evaluating. The outcomes of the program held is the farmer group of South Montong Baan has potential things to produce organic fertizer (compose) from domestic scale by using waste such as kitchen stuff and liquid and process takes about 2 till 3 weeks for the fertilizer to be used. The outcomes from monitoring and evaluating showed that the application of organic fertilizer made from domestic waste can decrease the use of inorganic fertilizer which in turn can reduce the expense of the farming activities and the local farmer group has also committed in developing organic fertilizer from the domestic waste as a sustainable effort of agricultural development programs.
\end{abstract}

Keywords: Composter, Domestic waste; Organic Fertilizer; 
Sehingga meninggalkan residu pada tanah, yang mengakibatkan pencemaran pada tanah dan hasilnya tanah akanmengalami degradasi. Pupuk anorganik akan menyebabkan struktur tanah menjadi keras dan unsur hara dalam tanah menjadi berkurang. Untuk itu diperlukan langkah konkret demi menjaga kelestarian lingkungan dan mengurangi ketergantungan terhadap pemakaian pupuk kimia. Salah satunya adalah dengan mengolah sampah organik menjadi pupuk padat dan cair.

Sampah rumah tangga merupakan salah satu penyumbang sampah terbesar kapada lingkungan. Penanggulangan sampah dapat kita mulai dari skala rumah tangga ini dengan memisahkan sampah organik dan anorganik. Sampah dapur sangat bermanfaat bisa digunakan seperti sampah sayur dan buah atau makanan yang sudah membusuk. Sampah-sampah tersebut akan diolah menjadi pupuk melalui alat komposter. Selain akan memenuhi kebutuhan akan unsur hara pada tanaman, dengan pembuatan pupuk organik ini maka kita akan mengurangi sampah-sampah yang sudah terlalu banyak. Berikut ini sampah organik yang akan dimanfaatkan adalah sampah-sampah rumah tangga organik. Berdasarkan latar belakang di atas kami melakukan penelitian Pengelolaan Sampah Rumah Tangga Menjadi Pupuk Organik Menggunakan Komposter Di Lingkungan Desa Montong Baan Selatan. Penelitian ini bertujuan untuk membuat pupuk organik dari sampah rumah tangga dengan menggunakan komposter.

Hasil yang diharapkan dari penelitian ini adalah dapat memberikan nilai jual pada sampah organik yang telah dijadikan pupuk organik, mengedukasi masyarakat untuk menggunakan alatalat disekitar untuk membuat alat komposter, menambah nilai guna terhadap sampah-sampah organik, dan dapat mengurangi ketergantungan para petani terhadap penggunaan pupuk kimia.

\section{Metode Pelaksanaan}

\section{Waktu dan Tempat}

Kegiatan dilakukan selama 4 minggu di mulai sejak tanggal 7 Februari sampai dengan 8 Maret di Desa Montong Baan Selatan, Kecamatan Sikur, Kabupaten Lombok Timur.

\section{Alat dan Bahan}

Alat yang digunakan untuk pembuatan komposter ini adalah bor listrik, lem pipa, spidol, gergaji besi, gunting, dan obeng besi. Sedangkan bahan-bahan yang diperlukan adalah ember plastik/ember bekas cat berdiameter $30 \mathrm{~cm}$, Pipa $1 / 2$ inch $1 \mathrm{~m}$ dan $1 \frac{1 / 4}{4}$ inch kurang lebih $35 \mathrm{~cm}$, lapis plastic / polycarbon, kain kasa, tali raffia, dan selang bening kurang lebih $10 \mathrm{~cm}$, dan penutup ember. Adapun bahan untuk membuat pupuk atau kompos adalah sampah dapur seperti potongan sisa sayuran, makanan busuk, daun kering, kotoran ternak, air, gula pasir / gula merah, dan cairan bakteri EM4.

\section{Prosedur Kerja Pembuatan Alat Komposter dan Pupuk Kompos.}

Prosedur kerja pembuatan alat komposter adalah: 1) Mempersiapkan alat dan bahan 2) Pemotongan pipa $1 / 2$ inch menjadi 3 bagian yang sama panjang dengan menggunakan spidol dan gergaji besi 3) Melubangi pipa $1 \frac{1 / 4}{4}$ inch dengan diameter sesuai pipa $1 / 2$ inch di ke 4 sisi yang salang berlawanan dengan jarak $10 \mathrm{~cm}$ dari sisi bawah dan 2 lubang berlawanan dengan menggunakan obeng besi yang dipanaskan,

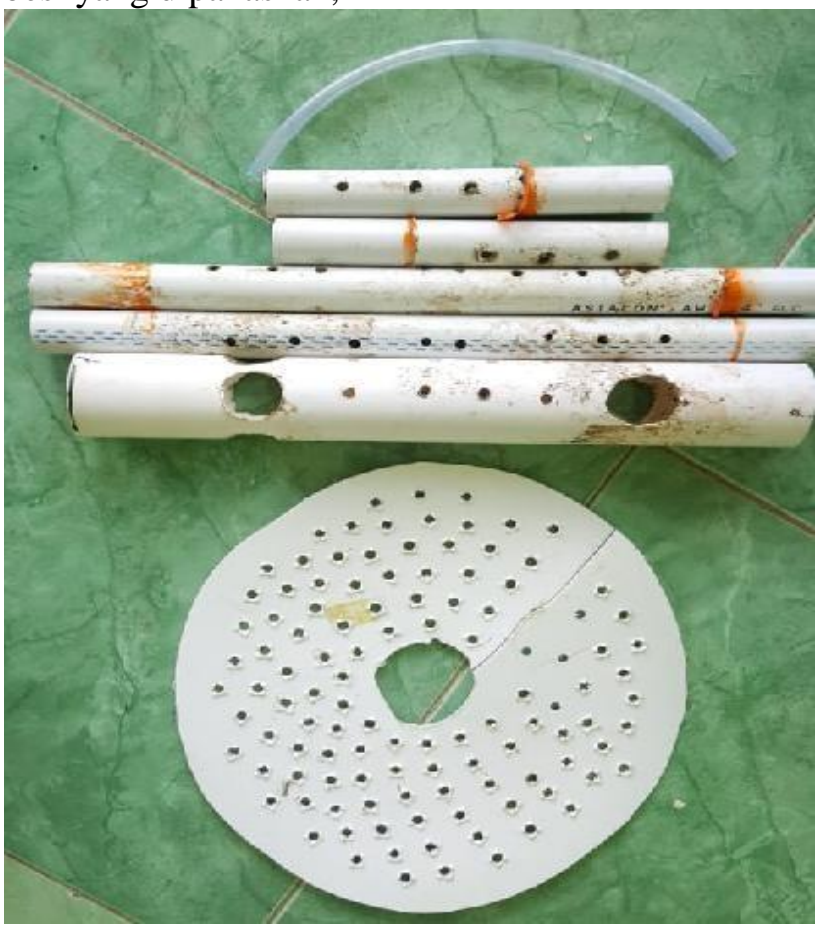

Gambar 1. Bagian dalam alat komposter 
4) Membuat 4 lubang di sisi kanan, kiri, depan, dan belakang emberdengan sejajar dengan spidol dan bor listrik sesuai diameter pipa $1 / 2$ inch yang berukuran $10 \mathrm{~cm}$ dari dasar ember,

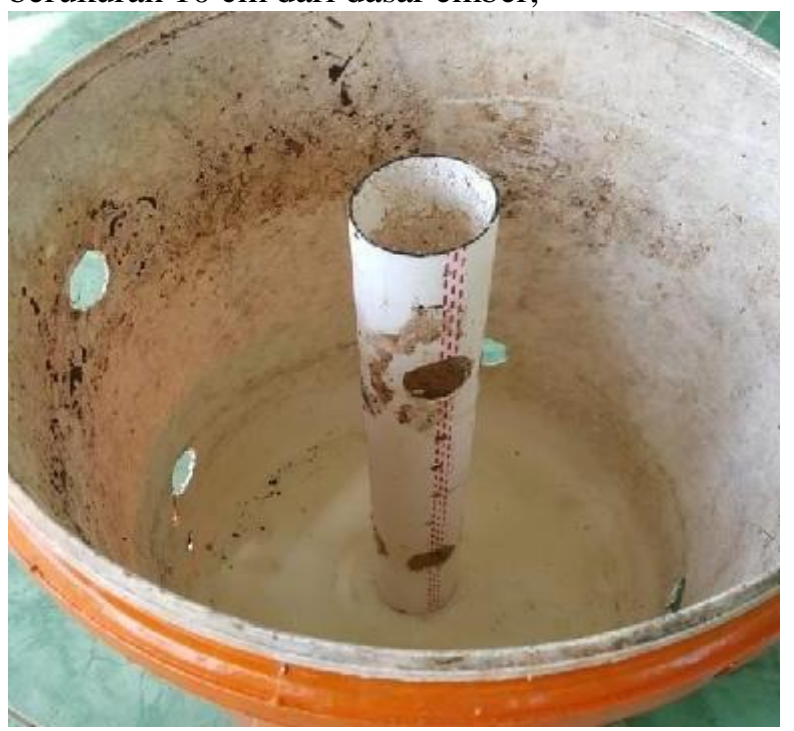

Gambar 2. Tampak dalam alat komposter

5) Membuat 2 lubang di sisi kanan dan kiri berukuran diameter pipa $1 / 2$ inch jarak 10 meter dari sisi atas ember, 6) Membuat 2 lubang kecil disisi dekat salah satu lubang yang satu berada di dekat dasar ember sebagai lubang selang bening untuk memanen pupuk cairnya,

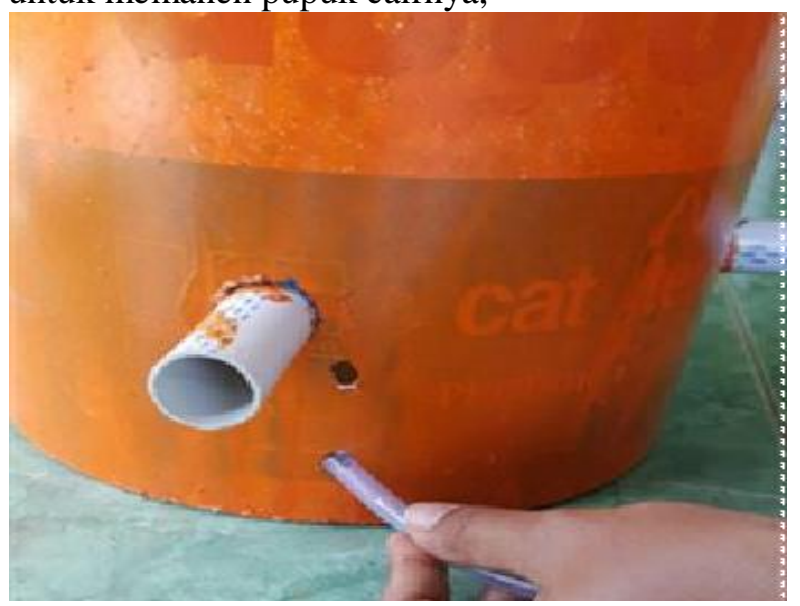

Gambar 3. Tempat Keluarnya Pupuk Cair

7) melubanginya kecil- kecil di sepanjang pipa di kedua sisinya, ini dilakukan dengan mengebor pad2 macam pipa diatas sebagai tempat saluran udara, 8) Menggunting polycarbon atau plastik membentuk lingkaran menyesuaikan dengan diameter ember dan diberikan lubang kecil-kecil dengan cara mengebor sebagai saringan, 9) setelah semua dipersiapkan, tinggal merakit alat komposter dengan menempatkan pipa $1 \frac{1 / 4}{4}$ inch ditengah dan memasang pipa $1 / 2$ inch di lubangnya yang sudah tersedia, kemudian meletakkan saringan plastik tersebut diatas pipa yang menyilang, semua pipa yang sudah dipasang dilubang direkatkan dengan lem pipa termasuk selang bening yang dibawah tetapi hanya lubang bawah yang di lem 10) menutup setiap lubang pipa yang keluar dari sisi ember dengan kain kasa dan diikat dengan tali raffia.

Prosedur kerja pembuatan pupuk kompos adalah: 1) Mempersiapkan alat dan bahan, 2) Menghaluskan/mencacah sampah organik yang terlalu besar 3) Memasukan sampah yang sudah dihaluskan, kotoran ternak , cairan EM4 dan gula dengan perbandingan 1:1 dan dilarutkan kedalam air dan semua dimasukkan ke dalam alat komposter 4) Mencampur dan mengaduk semua bahan, 5) Menutup ember dengan erat, 6) Mendiamkan selama 2-3 minggu 7) jika cairan sudah terlihat di selang bening maka pupuk cair sudah bisa dipanen

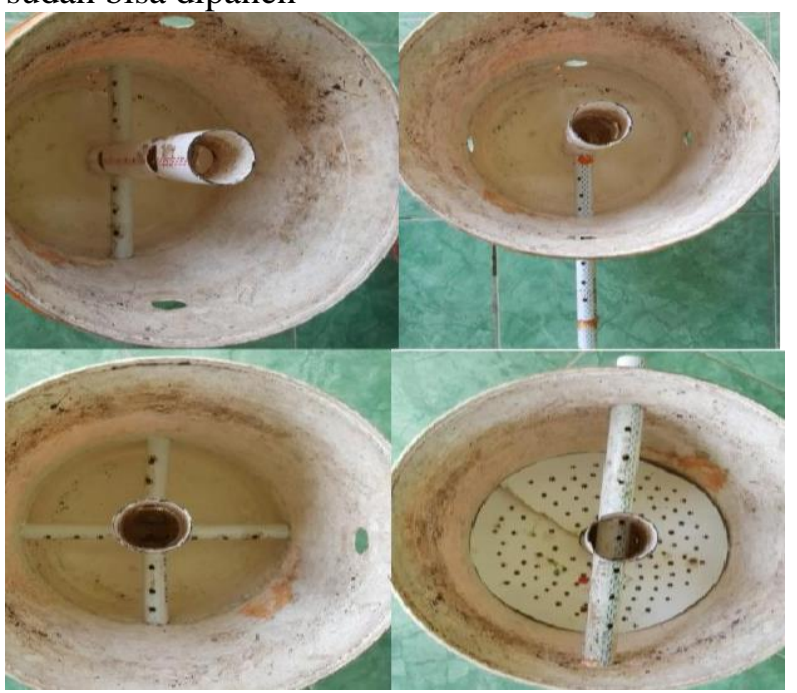

Gambar 4. Tampak dalam alat komposter setelah alat lain terpasang

\section{Bentuk Kegiatan}

Bentuk kegiatan secara keseluruhan ini adalah 1) Persiapan program, 2) Sosialisasi tentang pemilahan sampah dan cara pembuatan komposter 3) Sosialisasi hasil kompos setelah 4 minggu 4) Pengaplikasian hasil pupuk kompos 5) Monitoring dan evaluasi. 


\section{Metode Pengumpulan dan Analisis Data}

Metode pengumpulan data pada program ini adalah dengan survei jumlah sampah rumah tangga dan penggunaan pupuk organik, Analisis data menggunakan deskriptif kualitatif.

\section{Hasil dan Pembahasan}

Program pemberdayaan masyarakat desa Montong Baan Selatan dilakukan secara tersetruktur dan melibatkan masyarakat secara langsung. Pelaksanaan Program Pemberdayaan Masyarakat Kegiatan pemberdayaan masyarakat ini dimulai dengan persiapan program yang meliputi survei lokasi. Hasil survei menunjukan bahwa kendala yang dihadapi masyarakat Montong Baan Selatan antara lain 1) Tidak adanya lokasi pembuangan/ pengumpulan sampah sementara, 2) banyak volume sampah setiap harinya, 3) tidak adanya alat penghancur sampah.

Tahap selanjutnya adalah persiapan instrumen monitoring dan evaluasi yaitu pengetahuan masyarakat, selanjutnya perijinan dan pembahasan program bersama aparat di kantor desa dan masyarakat Montong Baan Selatan Kecamatan Sikur, Kabupaten Lombok Timur.

\section{Sosialisasi Pembuatan Alat Komposter dan Pupuk Kompos}

Sosialisasi sampah dan pembuatan pupuk kompos di desa Montong Baan Selatan dilakukan di halaman kantor desa Montong Baan Selatan. Sosialisasi pertama tentang pemisahan sampah rumah tangga, sampah organik dan anorganik yang dimana dihadiri 12 orang yang terdiri dari staff desa, ketua kelompok tani, ketua dusun, masyarakat sekitar dimana beberapa adalah petani

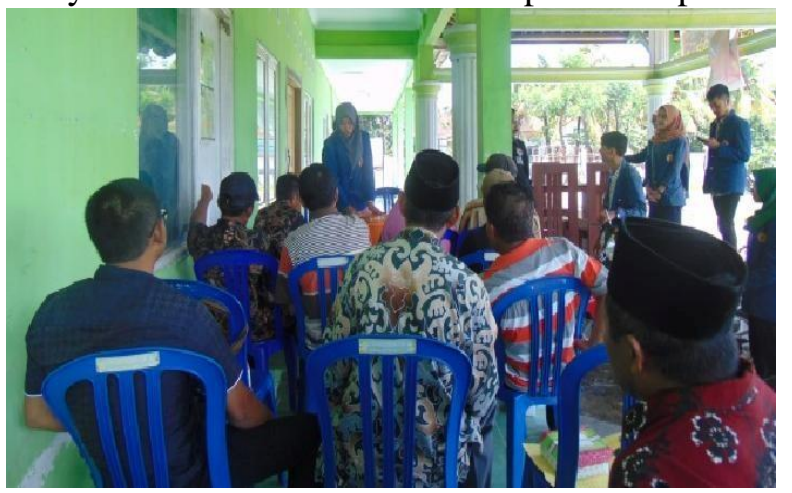

Gambar 5. Sosialisasi pengolahan sampah rumah tangga tahap pertama
Sosialisasi ini diadakan untuk pengenalan program kerja utama dan mengedukasi masyarakat tentang macam-macam sampah dan manfaatnya sebagai pupuk kompos, juga cara membuat alat komposter yang murah karena alat dan bahan dapat ditemukan disekitar menggunakan barang bekas.

Sosialisasi kedua yaitu mengenai hasil pupuk kompos dari alat komposter setelah 4 minggu yangdihadiri oleh 29 orang dimana sebagian besar adalah warga sekitar kantor desa. Ini adalah sosialisasi untuk memperlihatkan hasil pupuk cair dan padat sebelum diaplikasikan ke tumbuhan yang ada di pekarangan kantor desa dan tanaman toga yang sudah ditanam di minggu-minggu sebelumnya.

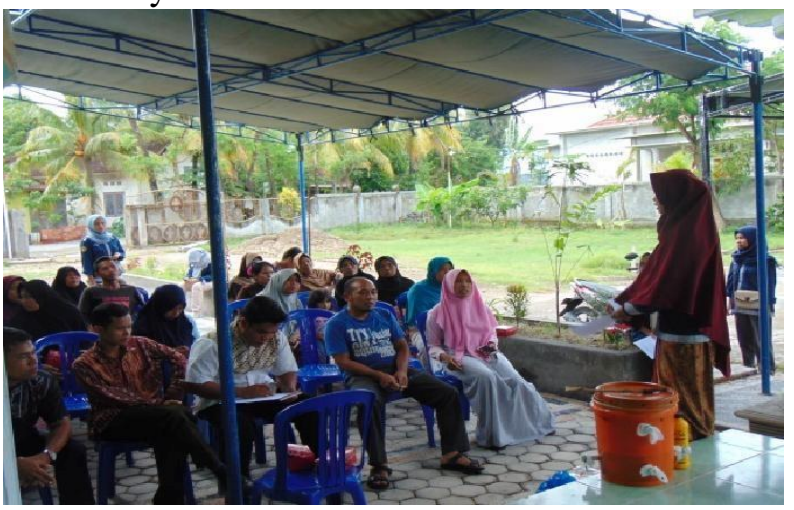

Gambar 6. Sosialisasi lanjutan pengolahan sampah rumah tangga tahap kedua

Dari sosialisasi diatas diharapkan dapat memberikan nilai jual pada sampah organik yang telah dijadikan pupuk organik, mengedukasi masyarakat untuk menggunakan alat-alat di sekitar untuk membuat alat komposter, menambah nilai guna terhadap sampah-sampah organik, dan dapat mengurangi ketergantungan para petani terhadap penggunaan pupuk kimia.

\section{Monitoring dan Evaluasi}

Monitoring dan evaluasi kontinu dilakukan bersamaan dengan pedampingan program. Hasil monitoring berkelanjutan Evaluasi program secara umum menunjukan bahwa masyarakat dan kelompok tani desa Montong Baan Selatan berkomitmen memanfaatkan dan mengolah sampah organik sebagai pupuk kompos dengan menggunakan alat komposter mengganti pupuk kimia untuk pengembangan pertanian yang lebih bagus. 


\section{Kesimpulan}

Simpulan dari program pengelolaan sampah rumah tangga menjadi pupuk kompos dengan menggunakan alat komposter sederhana kepada masyarakat adalah masyarakat Montong Baan Selatan dapat mengolah sampah organik untuk dijadikan sebagai pupuk pertanian.Selain menggunakan biaya yang sedikit juga dapat menjaga kebersihan lingkungan yang sehat dan indah dan masyarakat berkomitmen untuk upaya mengembangkan berkelanjutan program.

\section{Daftar Pustaka}

Djuarni, Nan.Ir, M.Sc., Kristian., Setiawan,Budi Susilo. 2006. Cara Cepat Membuat Kompos. Jakarta: AgroMedia.Hal 36-38

Hadisuwito, Sukamto. 2004. Membuat Pupuk Kompos Cair. Jakarta: Agromedia

Indriani, Y.H., 2007. Membuat Pupuk Organik Secara Singkat. Jakarta: Penebar Swadaya

Mashita, Nusa, dkk. 2008. Pengaruh Agen Dekomposer Terhadap Hasil Kualitas Hasil Pengomposan Sampah Organik Rumah Tangga. Sekolah Ilmu

Rohendi, E. 2005. Lokakarya Sehari Pengelolaan Sampah Pasar DKI Jakarta, sebuah prosiding. Bogor, 17 Februari 2005

Siburian, R. 2008. Pengaruh Konsentrasi dan Waktu Inkubasi EM4 Terhadap Kualitas Kimia Kompos. Jurusan Kimia, Fak. Sains dan Teknik Universitas Nusa Cendana, Kupang

Suriadikarta, Didi Ardi., Simanungkalit, R.D.M. 2006. Pupuk Organik dan Pupuk Hayati. Jawa Barat: Balai Besar Penelitian dan Pengembangan Sumberdaya Lahan Pertanian. Hal 2.

Sutanto, Rachman. 2002. Pertanian organik: Menuju Pertanian Alternatif dan Berkelanjutan. Jakarta: Kanisius. Teknologi Hayati, ITB, Bandung.
Moerdjoko S, Widyatmoko. 2012. Menghindari, Mengolah dan Menyingkirkan Sampah. Cet.1. PT. Dinastindo Adiperkasa Internasional, Jakarta.

Yuniwati, M., Iskarima, F., dan Padulemba, A., 2012. Optimisasi Kondisi Proses Pembuatan Kompos Dari Sampah Organik Dengan Cara Fermentasi Menggunakan EM4. Jurnal Teknologi, Vol. 5, No. 2 